\title{
Przedoperacyjna ocena kardiologiczna pacjentów poddawanych operacjom pozasercowym
}

\author{
Pre-operative cardiological assessment \\ of patients undergoing non-cardiac surgery
}

\author{
Gabriela Parol $^{1}$, Anna Ścibisz ${ }^{1}$, Andrzej Cacko ${ }^{1,2}$ \\ ${ }^{1}$ I Katedra i Klinika Kardiologii Warszawskiego Uniwersytetu Medycznego \\ ${ }^{2}$ Zakład Informatyki Medycznej i Telemedycyny Warszawskiego Uniwersytetu Medycznego
}

\section{Streszczenie}

Ocena ryzyka przedoperacyjnego u pacjentów z chorobami układu sercowo-naczyniowego powinna obejmować, poza stanem klinicznym oraz wydolnością chorego, ryzyko związane z procedurą chirurgiczną i rodzajem znieczulenia. Powinna być dostosowana do stanu pacjenta i pilności zabiegu. Wielu pacjentów w stabilnym stanie, kwalifikowanych do operacji o małym lub pośrednim ryzyku, po ocenie kardiologicznej, może być poddanych zabiegowi bez wykonywania badań dodatkowych. W przypadku osób obciążonych klinicznymi czynnikami ryzyka, zwłaszcza poddawanych procedurom chirurgicznym wysokiego ryzyka, wnikliwa ocena kardiologiczna uzupełniona badaniami dodatkowymi oraz optymalizacja farmakoterapii pomaga przygotować chorego do zabiegu i zminimalizować ryzyko powikłań sercowo-naczyniowych w okresie okołooperacyjnym.

Słowa kluczowe: przedoperacyjna ocena ryzyka sercowo-naczyniowego, operacje pozasercowe

Folia Cardiologica 2016; 11, 1: 66-74

\section{Wstęp}

Powikłania ze strony układu sercowo-naczyniowego u pacjentów po operacjach pozasercowych zależą od ryzyka ze strony pacjenta (związanego z jego obciążeniami), rodzaju operacji i okoliczności, w jakich do niej dochodzi, oraz od rodzaju znieczulenia. Czynniki „chirurgiczne” wpływające na ryzyko sercowo-naczyniowe to tryb operacji (pilna, planowa), inwazyjność, typ operacji i czas trwania, jak również wahania temperatury ciała, utrata krwi i przesunięcia płynów wewnątrzustrojowych. Poza tym każda operacja wywołuje odpowiedź stresową, która poprzez uszkodzenie tkanek i związaną z tym odpowiedź neuroendokrynną może prowadzić do zaburzeń równowagi współczulno-przywspółczulnej. Uogólniona reakcja stresowa prowadzi do zwiększonego zapotrzebowania mięśnia sercowego na tlen. Zabieg chirurgiczny wywołuje także zaburzenia równowagi między czynnikami prozakrzepowymi i fibrynolitycznymi, prowadząc potencjalnie do zwiększonej gotowości prozakrzepowej w tętnicach wieńcowych.

Ze względu na stopień ryzyka sercowo-naczyniowego zabiegi operacyjne podzielono na trzy grupy (tab. 1).

Ocena kardiologiczna pacjentów przed operacjami pozasercowymi jest istotna z dwóch powodów. Po pierwsze pacjenci cechujący się przewidywanym niskim ryzykiem mogą być poddani interwencji chirurgicznej obarczonej niskim lub pośrednim ryzykiem bez dodatkowej oceny kardiologicznej. Po drugie redukcja ryzyka poprzez farmakoterapię jest najbardziej efektywna kosztowo u pacjentów obciążonych spodziewanym podwyższonym ryzykiem sercowym. Część chorych wymaga natomiast podejścia multidyscyplinarnego - oceny przez zespół złożony z anestezjologa, kardiologa, chirurga, a także internisty, specjalisty intensywnej opieki, pulmonologa i geriatry. Gdy wskazania do operacji są 
Tabela 1. Ryzyko związane z rodzajem operacji* (na podstawie [1])

\begin{tabular}{|c|c|}
\hline Stopień ryzyka & Rodzaj operacji \\
\hline \multirow[t]{10}{*}{ Duże ryzyko (> 5\%) } & Operacje naczyniowe (chirurgia aorty i dużych naczyń) \\
\hline & Operacyjna rewaskularyzacja kończyn dolnych lub amputacja, lub embolektomia \\
\hline & Operacja w obrębie dwunastnicy i trzustki \\
\hline & Resekcja wątroby, operacja w obrębie dróg żółciowych \\
\hline & Wycięcie przełyku \\
\hline & Operacja z powodu perforacji jelit \\
\hline & Adrenalektomia \\
\hline & Radykalna cystektomia \\
\hline & Resekcja płuca \\
\hline & Przeszczepienie płuc lub wątroby \\
\hline \multirow[t]{9}{*}{ Pośrednie ryzyko (1-5\%) } & $\begin{array}{l}\text { Zabiegi wewnątrzotrzewnowe: splenektomia, operacja przepukliny rozworu przełykowego przepony, } \\
\text { cholecystektomia, operacje z otwarciem klatki piersiowej lub jamy otrzewnej }\end{array}$ \\
\hline & $\begin{array}{l}\text { Zabiegi naczyniowe w obrębie tętnic szyjnych u pacjentów z objawami (endarteriektomia } \\
\text { lub angioplastyka z wszczepieniem stentu) }\end{array}$ \\
\hline & Angioplastyka tętnic obwodowych \\
\hline & Wewnątrznaczyniowa naprawa tętniaka aorty \\
\hline & Operacje w obrębie głowy i szyi \\
\hline & Duże operacje ortopedyczne i neurochirurgiczne (stawu biodrowego i kręgosłupa) \\
\hline & Przeszczepienie nerki \\
\hline & Duże operacje urologiczne i ginekologiczne \\
\hline & Mniejsze operacje z otwarciem klatki piersiowej \\
\hline \multirow[t]{11}{*}{ Małe ryzyko (<1\%) } & Operacje w obrębie powłok brzusznych \\
\hline & Zabiegi stomatologiczne \\
\hline & Operacje okulistyczne \\
\hline & Operacje endokrynologiczne \\
\hline & Operacja sutka \\
\hline & Zabiegi rekonstrukcyjne \\
\hline & Operacje 1 dnia (ambulatoryjne) \\
\hline & Małe operacje ginekologiczne \\
\hline & Małe zabiegi ortopedyczne (np. stawu kolanowego) \\
\hline & Małe zabiegi urologiczne (przezcewkowa resekcja gruczołu krokowego) \\
\hline & $\begin{array}{l}\text { Zabiegi naczyniowe w obrębie tętnic szyjnych u pacjentów bez objawów (endarteriektomia } \\
\text { lub angioplastyka z wszczepieniem stentu) }\end{array}$ \\
\hline
\end{tabular}

*Zgon lub zawał serca niezakończony zgonem w ciągu 30 dni od operacji po uwzględnieniu jedynie specyfiki interwencji chirurgicznej bez względu na obciążenia pacjenta

pilne, to ocenę, a zwłaszcza badania dodatkowe, należy ograniczyć [1].

\section{Ocena ryzyka okołooperacyjnego}

U chorego kwalifikowanego do planowej operacji pozasercowej poza ryzykiem związanym z samą operacją należy uwzględnić również tak zwane kliniczne czynniki ryzyka powikłań sercowo-naczyniowych (tab. 2). Przydatnym i ciągle stosowanym narzędziem w ocenie przedoperacyjnej pacjentów z obciążeniami ze strony układu sercowo- -naczyniowego jest wskaźnik Lee (skorygowane ryzyko sercowe) - zmodyfikowana wersja wcześniejszejszego wskaźnika Goldmana, zaprojektowana do oceny ryzyka wystąpienia pooperacyjnego zawału serca, obrzęku płuc, migotania komór, nagłego zatrzymania krążenia czy bloku całkowitego. Skala ta uwzględnia rodzaj operacji, wywiad w kierunku choroby wieńcowej (CHD, coronary heart disease) i niewydolności serca, choroby naczyniowej mózgu, cukrzycy wymagającej leczenia insuliną i niewydolności nerek ze stężeniem kreatyniny ponad $2 \mathrm{mg} / \mathrm{dl}$ (> $170 \mu \mathrm{mol} / \mathrm{l})$. 
Tabela 2. Kliniczne czynniki ryzyka okołooperacyjnych powikłań sercowo-naczyniowych (na podstawie [1])

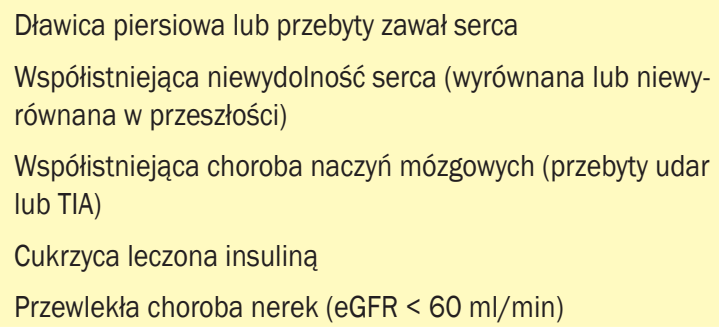

TIA (transient ischaemic attack) - przemijający atak niedokrwienny; eGFR (estimated glomerular filtration rate) - szacowany wskaźnik filtracji kłębuszkowej

Ze względu na postęp, jaki się dokonał w leczeniu CHD, jak również w rozwoju technik operacyjnych i anestezjologicznych, ostatnio zaproponowano nowy model predykcyjny do oceny ryzyka śród- i pooperacyjnego zawału serca lub zatrzymania krążenia przy użyciu programu NSQIP (American College of Surgeons National Surgical Quality Improvement Program; http://www.surgicalriskcalculator.com/ /miorcardiacarrest). Model ten uwzględnia pięć czynników okołooperacyjnego zawału serca lub zatrzymania krążenia do 30 dni po operacji: rodzaj operacji, stan czynnościowy, podwyższone stężenie kreatyniny (> 1,5 mg/dl lub $>130 \mu \mathrm{mol} / \mathrm{I}$ ), klasę według American Society of Anesthesiologists (ASA) (tab. 3) i wiek pacjenta [2, 3].

\section{Badania dodatkowe}

Dodatkowe nieinwazyjne badania obrazowe służą identyfikacji chorych obciążonych wyższym ryzykiem; celem badań jest zdobycie informacji dotyczącej trzech sercowych markerów ryzyka - dysfunkcji lewej komory (LV, left ventricle), niedokrwienia mięśnia sercowego oraz dysfunkcji zastawek, choć powinny być zarezerwowane jedynie dla tych chorych, u których oczekuje się, że wyniki tych badań wpłyną na zmianę postępowania. Większość osób ze stabilną CHD może być poddana interwencji chirurgicznej obarczonej niskim lub pośrednim ryzykiem bez dodatkowej oceny. Również u chorych po pomostowaniu aortalno-wieńcowym (CABG, coronary artery by-pass grafting) do 6 lat od zabiegu, o ile nie wystąpił nawrót choroby, nie ma potrzeby wykonywania dodatkowych badań nieinwazyjnych czy inwazyjnych. Z kolei chorych po angioplastyce wieńcowej (PTCA, percutaneous coronary angioplasty) cechuje zwiększone ryzyko zdarzeń sercowych po zabiegu chirurgicznym, zwłaszcza w przypadku operacji nieplanowych, w krótkim czasie po PTCA. Dlatego, o ile to możliwe, u chorych po PTCA zabiegi planowe należy odroczyć, także ze względu na stosowanie leków przeciwpłytkowych (tab. 4).

\section{Ocena wydolności wysiłkowej}

Kluczowym czynnikiem w przedoperacyjnej ocenie ryzyka sercowo-naczyniowego jest ocena wydolności wysiłkowej wyrażanej w równoważnikach metabolicznych (MET, metabolic equivalent). Jeden MET odpowiada przeciętnemu wydatkowi energetycznemu w spoczynku. Obiektywną ocenę wydolności wysiłkowej zapewnia test wysiłkowy, poza tym służy ocenie niedokrwienia oraz odpowiedzi tensyjnej i chronotropowej na wysiłek. Jeżeli wykonanie testu wysiłkowego jest niemożliwe, to wydolność wysiłkową można oszacować na podstawie zdolności do wykonywania

Tabela 3. Klasyfikacja według American Society of Anesthesiologists (ASA) (źródło [4])

I Pacjent bez obciążeń poddawany operacji o małym lub średnim ryzyku

II Pacjent z niezbyt nasiloną chorobą układową: dobrze kontrolowane nadciśnienie tętnicze, wyrównana cukrzyca, COPD w stadium wydolności układu oddechowego, stabilna choroba wieńcowa, niedokrwistość, otyłość znacznego stopnia

III Pacjent z ciężką chorobą układową, która ogranicza jego wydolność: zawał serca przebyty do 3 miesięcy temu, niestabilna choroba wieńcowa, ciężkie schorzenia układu oddechowego, niewyrównana cukrzyca

IV Pacjent z bardzo ciężką chorobą układową zagrażającą jego życiu, np. niewydolność nerek, niewydolność serca, wada serca z ostra niewydolnością serca, ostry zawał serca, niewydolność wątroby lub innych narządów

V Pacjent z niewydolnością wielonarządową w stanie skrajnie ciężkim, z rokowaniem co do przeżycia $<24 \mathrm{~h}$

COPD (chronic obstructive pulmonary disease) - przewlekła obturacyjna choroba płuc

Tabela 4. Czas odroczenia planowych operacji u pacjentów po interwencjach wieńcowych

$\begin{array}{lcc}\text { Rodzaj interwencji } & \text { Optymalny czas odroczenia operacji } & \text { Minimalny czas odroczenia operacji } \\ \text { POBA } & 2 \text { tygodnie } & 4 \text { tygodnie } \\ \mathrm{PCl} \text { z implantacją BMS } & 3 \text { miesiące } & 3 \text { miesiące (w przypadku DES nowej generacji) } \\ \mathrm{PCl} \text { z implantacją DES } & 6 \text { miesięcy } \\ \mathrm{ACS} & 12 \text { miesięcy niezależnie od typu rewaskularyzacji } & \end{array}$

POBA (plain old balloon angioplasty) - angioplastyka balonowa; PCI (percutaneous coronary intervention) - przezskórna interwencja wieńcowa; BMS (bare-metal stent) - stent metalowy; DES (drug-eluting stent) - sten uwalniający lek antyproliferacyjny; ACS (acute coronary syndrome) - ostry zespół wieńcowy 


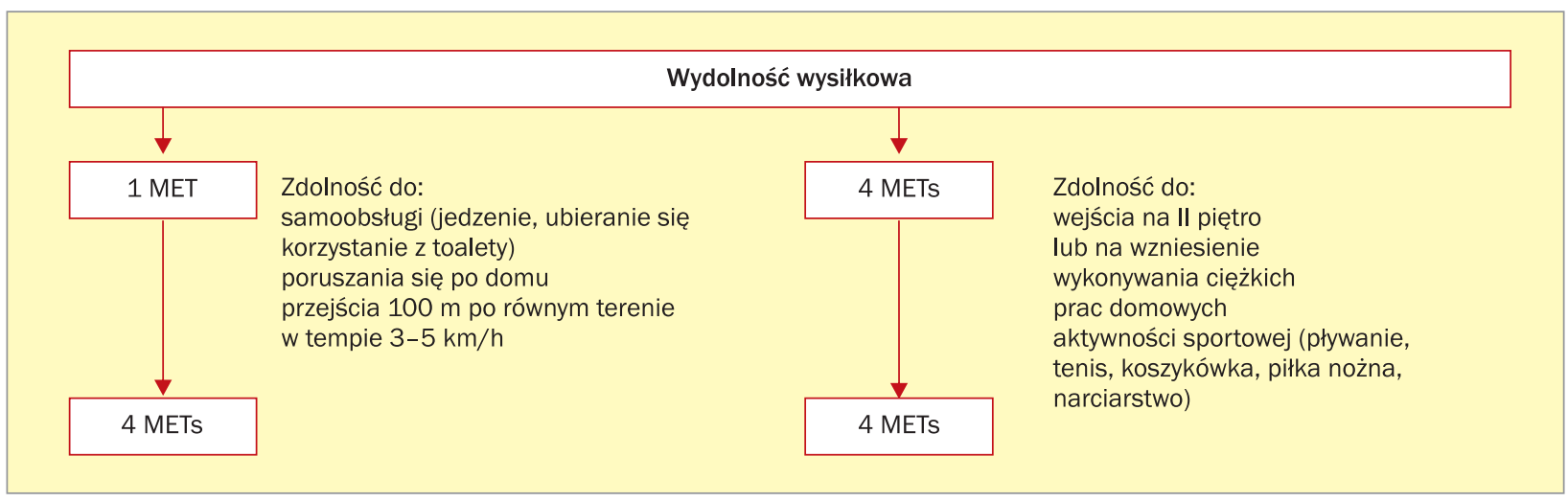

Rycina 1. Szacowny wydatek energetyczny dla różnych aktywności (na podstawie [1]); MET (metabolic equivalent) - równoważnik metaboliczny

codziennych czynności (ryc. 1). Niezdolność do wejścia na II piętro (< 4 METs) wskazuje na słabą wydolność wysiłkową i wiąże się ze zwiększonym ryzykiem niekorzystnych zdarzeń w okresie pooperacyjnym. Gdy zaś wydolność wysiłkowa jest bardzo dobra, to prognoza również jest dobra, nawet u pacjentów ze stabilną CHD lub obciążonych czynnikami ryzyka. U pacjentów niezdolnych do wykonania wysiłku na bieżni można wykonać obrazowe badanie obciążeniowe (scyntygrafię perfuzyjną lub echokardiografię obciążeniową), a u chorych z niewydolnością serca - sercowo-płucny test wysiłkowy (CPX, cardiopulmonary exercise test).

\section{Badanie elektrokardiograficzne}

Rutynowe badanie elektrokardiograficzne (EKG) nie jest konieczne u chorych bez czynników ryzyka poddawanych operacjom o małym ryzyku. Badanie to zaleca się u chorych obciążonych czynnikami ryzyka, poddawanych operacjom o pośrednim lub wysokim ryzyku. Można je również rozważyć u chorych obciążonych czynnikami ryzyka, poddawanych operacjom o małym ryzyku, a także u chorych powyżej 65. roku życia, bez czynników ryzyka, poddawanych operacjom o wysokim ryzyku.

\section{Badanie echokardiograficzne}

Również badanie echokardiograficzne nie jest konieczne u wszystkich chorych. Rutynowo nie zaleca się go u pacjentów poddawanych operacjom o małym lub pośrednim ryzyku. Należy je rozważyć u chorych poddawanych operacjom o wysokim ryzyku, a także u osób z rozpoznaną lub podejrzewaną niewydolnością serca. Echokardiografia jest kluczowa w ocenie frakcji wyrzutowej lewej komory (LVEF, left ventricular ejection fraction), objętości LV i przedsionków, w ocenie funkcji zastawek i funkcji rozkurczowej LV, jak również - poprzez ocenę żyły głównej dolnej - ma istotne znaczenie w ocenie stanu wolemii i ciśnienia w prawym przedsionku. Badanie echokardiograficzne należy wykonać u pacjentów z wadą zastawkową serca kwalifikowanych do zabiegów o pośrednim i wysokim ryzyku.

\section{Badania obciążeniowe}

Echokardiografia obciążeniowa (wysiłkowa lub z zastosowaniem dobutaminy) jest szeroko stosowana w przedoperacyjnej ocenie ryzyka sercowego. Dostarcza informacji o funkcji LV w spoczynku, nieprawidłowości w obrębie zastawek i obecności oraz zakresie niedokrwienia indukowanego obciążeniem. Ma wysoką ujemną wartość predykcyjną. Tomografia emisyjna pojedynczego fotonu (SPECT, single-photon emision computer tomography) jest istotna w ocenie ryzyka przedoperacyjnego, zwłaszcza u pacjentów z niską wydolnością wysiłkową. Obciążenie farmakologiczne (dipirydamolem, adenozyną lub dobutaminą) jest alternatywą dla chorych z niską wydolnością wysiłkową. Rezonans magnetyczny serca z obciążeniem farmakologicznym ma swoje miejsce w ocenie niedokrwienia indukowanego obciążeniem, jednak jest badaniem trudniej dostępnym.

Wykonanie obrazowych badań obciążeniowych zaleca się u chorych obarczonych więcej niż dwoma klinicznymi czynnikami ryzyka, z małą wydolnością wysiłkową (u chorych, którzy nie są w stanie pokonać obciążenia 4 METs = wejście na Il piętro), zwłaszcza kwalifikowanych do operacji o dużym ryzyku, a ich rozważenie - także u chorych obciążonych 1-2 klinicznymi czynnikami ryzyka, kwalifikowanych do operacji o pośrednim lub wysokim ryzyku, który wydolność wysiłkowa jest obniżona (< 4 METs).

\section{Koronarografia}

Koronarografia jest rzadko wskazana w ocenie ryzyka u pacjentów poddawanych planowym operacjom pozasercowym. Niekiedy wykonanie badania może spowodować niespodziewane odroczenie planowego zabiegu. Mimo że CHD może występować u wielu pacjentów poddawanych interwencji chirurgicznej, to wskazania do wykonania koronarografii i ewentualnej rewaskularyzacji przed planowaną interwencją chirurgiczną są podobne do wskazań w ogólnej populacji pacjentów. Przedoperacyjne leczenie niedokrwienia mięśnia sercowego - zarówno zachowawcze, jak i inwazyjne - zaleca się bez względu na to, czy operacja może być odroczona. 
Planową koronarografię należy rozważyć u chorych w stabilnym stanie kwalifikowanych do operacji o dużym ryzyku. Należy ją wykonać jedynie wtedy, gdy bierze się pod uwagę możliwość leczenia inwazyjnego przed operacją pozasercową. Rewaskularyzacja przed zabiegiem nie wiąże się z istotną poprawą przeżywalności, nawet u chorych z wielonaczyniową CHD, dlatego należy dążyć do optymalizacji leczenia farmakologicznego.

\section{Rodzaje znieczulenia i związane z nimi ryzyko sercowo-naczyniowe}

Rodzaj znieczulenia do zabiegu operacyjnego zależy od rodzaju zabiegu, jego rozległości, ale również od stanu pacjenta i obciążeń współistniejących. Najczęściej stosowaną skalą do oceny ryzyka znieczulenia jest, wspomniana już, skala ASA (patrz tab. 3). Odpowiednie znieczulenie powinno zapewnić zarówno optymalne warunki dla operującego chirurga, właściwy stopień analgezji i amnezję okołooperacyjną, jak i możliwie jak najmniejsze działania niepożądane na układ sercowo-naczyniowy. Najmniej obciążającym rodzajem znieczulenia, które można zastosować w przypadku drobnych zabiegów, jest anestezja miejscowa związana z niewielkim ryzykiem powikłań układu sercowo-naczyniowego. Zmniejszenie aktywności układu współczulnego, do którego dochodzi w przypadku innych niż miejscowe rodzajów znieczulenia, może prowadzić do śródoperacyjnych spadków ciśnienia tętniczego, co zwiększa ryzyko okołooperacyjnych zgonów, zawałów serca czy powikłań niedokrwiennych ze strony ośrodkowego układu nerwowego.

Znieczulenie podpajęczynówkowe i zewnątrzoponowe (zwane łącznie znieczuleniem neuroosiowym), w świetle aktualnych wytycznych European Society of Cardiology (ESC), można rozważyć u pacjentów z obciążającym wywiadem w kierunku chorób układu sercowo-naczyniowego ze względu na zmniejszenie chorobowości iumieralności. Duże zabiegi operacyjne w obrębie jamy brzusznej, klatki piersiowej, neurochirurgiczne oraz inne długotrwałe interwencje chirurgiczne wymagają znieczulenia ogólnego prowadzonego wraz z intubacją i wentylacją mechaniczną. Ostrożność powinna być zachowana już na etapie wprowadzania do znieczulenia. Propofol oraz barbiturany moga doprowadzić do hipotonii, toteż u pacjentów z obciążeniami ze strony układu sercowo-naczyniowego lepszym wyborem będzie etomidat, z kolei podanie ketaminy może skutkować tachykardią. Środkiem zwiotczającym z wyboru u pacjentów obciążonych kardiologicznie jest zwykle norkuron $[5,6]$.

\section{Przygotowanie do operacji pacjenta $z$ implantowanym urządzeniem do elektroterapii serca}

Z punktu widzenia lekarza chirurga szczególną grupą chorych powinny być osoby z implantowanym urządzeniem do elektroterapii serca. Układy stymulujące serca (PM, pacemaker) wszczepia się pacjentom z bradyarytmią, a implantowany kardiowerter-defibrylator (ICD, implantable cardioverter-defibrillator) - chorym zagrożonym tachyarytmią komorową.

W trakcie badania przedmiotowego nie wolno pominąc oceny loży urządzenia, najczęściej zlokalizowanej w lewej okolicy podobojczykowej. Inne możliwe lokalizacje to prawa okolica podobojczykowa i (bardzo rzadko) nadbrzusze. Najnowsze ICD, wyposażone jedynie w elektrodę podskórną, implantuje się pod lewą okolicą pachową. Jakiekolwiek objawy infekcji widoczne w okolicy loży (zaczerwienienie, obrzęk, chełbotanie) wymagają pilnej weryfikacji przed planowaną operacją. Zakażenie loży urządzenia jest równoznaczne z zakażeniem elektrod i najczęściej wymaga specjalistycznego postępowania (antybiotykoterapia, usunięcie układu).

Użycie elektrokoagulacji podczas zabiegu operacyjnego może spowodować zaburzenia wyczuwania wszczepionego układu. Prąd płynący przez ciało pacjenta może zostać wykryty przez układ i interpretowany jako własne pobudzenia serca i hamować stymulację. U pacjentów stymulatorozależnych (bez rytmu własnego komór lub z własnym rytmem serca niewydolnym hemodynamicznie z powodu zbyt wolnej częstości) zahamowanie stymulacji skutkuje znacznym zwolnieniem częstości rytmu serca lub pauzą w trakcie elektrokoagulacji. Układy ICD programuje się tak, aby interpretowały szybką czynność elektryczną w kanale komorowym jako migotanie komór. Dlatego u pacjentów z ICD interferencja zostanie zinterpretowana jako migotanie komór i urządzenie rozpocznie ładowanie kondensatorów, a jeżeli czas trwania elektrokoagulacji będzie odpowiednio długi (kilka-kilkanaście s) lub kolejne serie elektrokoagulacji będą następować bezpośrednio po sobie, to urządzenie dostarczy terapię wysokoenergetyczną. W celu obniżenia ryzyka interferencji zaleca się stosowanie elektrokoagulacji bipolarnej, aplikacje elektrokoagulacji w krótkich seriach (do 3 s) z przerwami (przynajmniej kilkusekundowymi). Detekcja tachyarytmii ICD powinna być wyłączona przed każdym zabiegiem - ryzyko interferencji maleje wraz z odległością pola operacyjnego od klatki piersiowej, przy czym obserwowano interferencje rejestrowane podczas operacji wytworzenia przetoki naczyniowej na przedramieniu czy operacji naczyniowych w obrębie kończyn dolnych. Jeśli w ośrodku nie ma możliwości kontroli układu ICD bezpośrednio przed zabiegiem, to detekcję tachyarytmii można wyłączyć, przytwierdzając (np. plastrem) magnes nad urządzeniem - magnes, tak długo, jak długo znajduje się nad urządzeniem (w niektórych urządzeniach tylko do 12 h), wyłącza detekcję tachyarytmii. Zaleca się konsultację postępowania z najbliższym lub zaprzyjaźnionym ośrodkiem prowadzącym kontrole pacjentów z implantowanymi układami PM i ICD. 
Nieodzownym elementem przygotowania pacjenta do zabiegu operacyjnego powinna być kontrola wszczepionego urządzenia. Osoba dokonująca kontroli powinna zostać poinformowana o planowanym zabiegu, w tym - planowanym zakresie i terminie operacji. Należy ocenić stymulatorozależność, wykluczyć zaburzenia stymulacji i wyczuwania (bez oceny stanu wyjściowego w przypadku późniejszego zdiagnozowania zaburzeń pracy układu można podejrzewać, że uszkodzenie nastąpiło podczas wykonanej procedury). Najważniejsze elementy oceniane podczas kontroli układów PM i ICD przedstawiono na rycinie 2. Jeżeli w trakcie kontroli przed zabiegiem modyfikowano parametry układu (zmiana trybu stymulacji, częstości stymulacji, wyłączenie detekcji tachyarytmii), to niezbędna jest kolejna kontrola po zabiegu [7, 8].

\section{Optymalizacja farmakoterapii u chorych poddawanych operacjom pozasercowym}

\section{Leki $\beta$-adrenolitycze}

Głównym wskazaniem do stosowania leków z tej grupy jest zmniejszenie zapotrzebowania na tlen przez mięsień sercowy poprzez spowolnienie częstości rytmu serca (HR, heart rate) prowadzące do wydłużenia rozkurczu i okresu napełniania LV oraz zmniejszenia jej kurczliwości. Leki $\beta$-adrenolityczne obniżają ryzyko okołooperacyjnego zawału serca i zgonu u chorych poddawanych operacjom o dużym ryzyku.

Większość pacjentów z obciążeniami ze strony układu sercowo-naczyniowego jest leczona lekami z grupy $\beta$-adrenolityków. Tego leczenia nie należy odstawiać przed

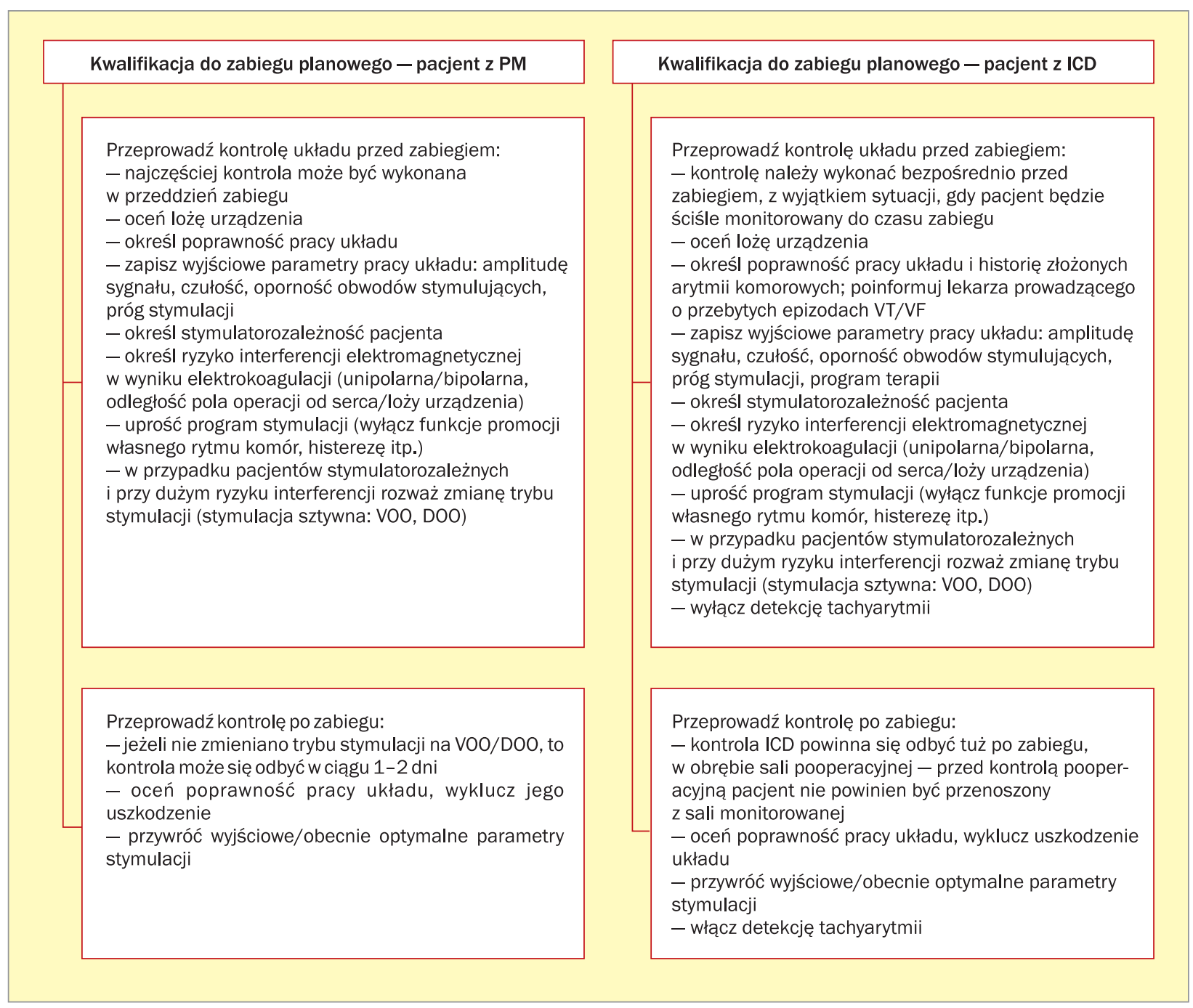

Rycina 2. Najważniejsze elementy kontroli pacjenta z wszczepionym układem stymulaującym serce (PM, pacemaker) lub implantowanym kardiowerterem-defibrylatorem (ICD, implantable cardioverter-defibrillator); VT (ventricular tachycardia) - częstoskurcz komorowy; VF (ventricular fibrillation) - migotanie komór 
planowaną operacją pozasercową (kontynuacja leczenia u chorych z nadciśnieniem tętniczym, zaburzeniami rytmu, niewydolnością serca), powinno się natomiast rozważyć wdrożenie $\beta$-adrenolityków u chorych ze stabilną CHD nieleczonych uprzednio lekami z tej grupy, a także u chorych obciążonych co najmniej dwoma klinicznymi czynnikami ryzyka kwalifikowanych do operacji o dużym ryzyku, w co najmniej III klasie według ASA. Leczenie należy wdrożyć na przynajmniej 7-30 dni przed planowanym zabiegiem i stopniowo zwiększać dawkę, dążąc do utrzymania czynności serca w granicach 60-70/min i skurczowego ciśnienia tętniczego ponad 100 mm Hg. Należy unikać bradykardii i hipotensji. Preferowanymi lekami z tej grupy są bisoprolol i atenolol.

\section{Statyny}

Leki z grupy statyn stabilizują blaszki miażdżycowe poprzez działania plejotropowe, co potencjalnie obniża ryzyko pęknięcia blaszki i zawału serca w okresie okołooperacyjnym. Statyny są szeroko stosowane u pacjentów z CHD. Pacjenci z miażdżycą w innych łożyskach niż wieńcowe (tętnice szyjne, kończyn dolnych, nerkowe, aorta) powinni przyjmować statynę w prewencji wtórnej, bez względu na kwalifikację do interwencji chirurgicznej. Statyny obniżają ryzyko pooperacyjnej niewydolności nerek i zmniejszają śmiertelność u chorych z powikłaniami pooperacyjnymi lub niewydolnością wielonarządową. Mogą także obniżać ryzyko wystąpienia migotania przedsionków w okresie pooperacyjnym. U chorych przyjmujących statynę przewlekle leczenie to należy kontynuować w okresie okołooperacyjnym, gdyż jej odstawienie może zwiększać ryzyko sercowo-naczyniowe. U osób dotychczas nieleczonych lekami z tej grupy, kwalifikowanych do operacji naczyniowych, statynę należy wdrożyć - optymalnie na 2 tygodnie dni przed zabiegiem.

\section{Inhibitory konwertazy angiotensyny i antagoniści receptora aldosteronowego}

Nie należy odstawiać inhibitorów konwertazy angiotensyny (ACE, angiotensin-converting enzyme) ani antagonistów receptora angiotensyny (ARB, angiotensin receptor blockers) u pacjentów leczonych z powodu niewydolności serca. 0 ile nie wdrożono ich wcześniej, o tyle należy je włączyć u tych chorych przynajmniej tydzień przed planowaną interwencją chirurgiczną. Ponieważ mogą powodować ciężką hipotensję, to zaleca się ewentualne pominięcie porannej dawki, by uniknąć hipotonii w trakcie zabiegu i okresie pooperacyjnym u pacjentów z nadciśnieniem tętniczym. U chorych w stabilnym stanie z niewydolnością serca leczenie należy kontynuować pod ścisłą kontrolą w okresie okołooperacyjnym.

\section{Diuretyki}

Diuretyki przyjmowane przez chorych z powodu nadciśnienia tętniczego i niewydolności serca powinny być utrzymane do dnia zabiegu. W przypadku niewydolności serca należy rozważyć zwiększenie dawki, gdy są obecne objawy retencji płynów. Jeśli pacjent ma hipowolemię, hipotensję lub zaburzenia elektrolitowe, to należy rozważyć zmniejszenie dawki.

\section{Kwas acetylosalicylowy}

Odstawienie kwasu acetylosalicylowego zwiększa ryzyko incydentów sercowo-naczyniowych, dlatego leczenie należy przerwać tylko w sytuacji, gdy ryzyko krwawień przewyższa ryzyko powikłań zakrzepowych. U chorych poddawanych operacjom w obrębie kręgosłupa, neurochirurgicznym czy okulistycznym optymalny czas odstawienia kwasu acetylosalicylowego wynosi przynajmniej $7 \mathrm{dni}$.

\section{Podwójna terapia przeciwpłytkowa}

W celu uniknięcia krwawienia u pacjentów poddanych podwójnej terapii przeciwpłytkowej (DAPT, double antiplatelet therapy) zaleca się odroczenie planowej interwencji chirurgicznej do czasu zakończenia pełnej zaleconej DAPT i, gdy to możliwe, przeprowadzenie operacji bez odstawiania kwasu acetylosalicylowego (tab. 4). U pacjentów wymagających interwencji chirurgicznej w ciągu kilku dni czas odstawienia leków przeciwpłytkowych wynosi 5 dni w przypadku klopidogrelu i tikagreloru i 7 dni w przypadku prasugrelu.

\section{Doustne antykoagulanty}

$\mathrm{U}$ pacjentów leczonych antagonistami witaminy K (VKA, vitamin $\mathrm{K}$ antagonist) operację można przeprowadzić bezpiecznie, gdy międzynarodowy współczynnik znormalizowany (INR, intarnational normalized ratio) nie przekracza 1. Jednak u pacjentów obciążonych dużym ryzykiem powikłań zakrzepowo-zatorowych (migotanie przedsionków $\mathrm{i} \geq 4$ pkt. w skali $\mathrm{CHA}_{2} \mathrm{DS}_{2}$-VASc, z zastawką mechaniczną lub niedawno wszczepioną protezą biologiczną, po naprawie zastawki mitralnej do 3 miesięcy temu, zakrzepicy żył do 3 miesięcy temu, z trombofilią) przerwanie leczenia doustnym VKA jest ryzykowne i wymaga terapii pomostowej heparyną niefrakcjonowaną (UFH, unfractioned heparin) lub terapeutycznymi dawkami heparyny drobnocząsteczkowej (LMWH, low molecular weight heparin). Ostatnia dawka LMWH powinna być podana 12 godzin przed planowaną operacją. Podawania VKA należy zaprzestać 3-5 dni przed planowaną operacją do uzyskania INR nieprzekraczającego 1,5, a LMWH lub UFH należy wdrożyć dzień po odstawienu VKA. Powrót do leczenia VKA w 2. lub 3. dobie po zabiegu zależy od hemostazy. Stosowanie LMWH lub UFH powinno być kontynuowane po zabiegu razem z VKA do czasu osiągnięcia terapeutycznych wartości INR (tab. 5) [9, 10]. U pacjentów poddawanych drobnym zabiegom o niskim ryzyku powikłań krwotocznych (np. usunięcia zaćmy czy małe zabiegi w obrębie skóry) można je przeprowadzić w trakcie leczenia VKA z założeniem, że INR pozostaje w niższym zakresie. 


\section{Piśmiennictwo}

1. Kristensen S.D., Knuuti J., Saraste A. i wsp. 2014 ESC/ESA guidelines on non-cardiac surgery: cardiovascular assessmnet and management of the euro pean Society of Cardiology (ESC) and European Society of Anaesthesiology (ESA). Eur. Heart J. 2014; 35: 2283-2431.

2. Lee T.H., Marcantonio E.R., Mangione C.M. i wsp. Derivation and prospective validation of a simple index for prediction of cardiac risk of major noncardiac surgery. Circulation 1999; 100: 1043-1049.

3. Gupta P.K., Gupta H., Sundaram A. i wsp. Development and validation of a risk calculator for prediction of cardiac risk after surgery. Circulation 2011; 124: 381-387.

4. ASA Physical Status Classification System. American Society of Anesthesiologists. Dostępne na: https://www.asahq.org/For-Members/ /Clinical-Information/ASA-Physical-Status-Classification-System.aspx. Data dostępu: 16.02.2016.

5. De Hert S., Imberger G., Carlisle J. i wsp. Preoperative evaluation of the adult patient udergoing non-cardiac surgery guidelines from the European Society of Anaesthesiology. Eur. J. Anaesthesiol. 2011; 28: 684-722.
6. Michalik E. Przedoperacyjna ocena i postępowanie okołooperacyjne u chorych w wieku podeszłym. Post. Nauk Med. 2008; 11: 712-721.

7. Healey J.S., Merchant R., Simpson C. i wsp. Canadian Cardiovascular Society/Canadian Anesthesiologists' Society/Canadian Heart Rhythm Society joint position statement on the peri-operative management of patients with implanted pacemakers, defibrillators and neurostimulating devices. Can. J. Cardiol. 2012; 28: 141-151.

8. Brignole M.,Auricchio A., Baron-Esquivias G. i wsp. 2013 ESC Guidelines on cardiac pacing and cardiac resynchronization therapy. The Task Force on cardiac pacing and resynchronization therapy of the European Society of Cardiology (ESC). Developed in collaboration with the European Heart Rhythm Association (EHRA). Eur. Heart J. 2013; 34: 2281-2329.

9. Stępińska J. Leczenie przeciwzakrzepowe i antyagregacyjne u chorych z wadami serca. W: Hryniewiecki T., Gąsior Z., Rużyło W. (red.). Wady serca. Medical Tribune, Warszawa 2013: 851-863.

10. Vahanian A., Alfieri O., Andreotti F. i wsp. Guidelines on the management of valvular heart disease (version 2012). Eur. Heart J. 2012; 33: 2451-2496. 